\title{
Command Theory of Law and Perils of Citizens*
}

\author{
Shahdeen Malik \\ Advocate, Supreme Court of Bangladesh
}

"... for I shall desire to talk with you on all subjects which engage me"-so wrote John Austin to Sarah Taylor and provided her, during their five-year long engagement, with an extensive reading list of books by Bentham. After their marriage in 1819, Austin took up residence near Bentham, and the Mill family also lived nearby. ${ }^{1}$

Austin was ".. an austere, reserved, gloomy, bookish yet highly ambitious member of Benthamite inner circle."

Irrespective of whether our law-makers fit the above description or not, the primary narrative of this article is to suggest that our law-makers are, perhaps unwittingly, Austinian in their outlook as our laws stem from their (law-makers') perception of law as a 'command of the sovereign'. And, hence, they 'command'. Whether, as a result, we citizens are at peril or not is the second part of this article. The third and last part delves into "natural law" as an explanatory variable to indicate our reluctance to take legal obligations seriously - a reluctance which, perhaps, is rooted in the disjunction between law and morality in our laws. This disjunction has originated in our overtemphasis on the 'command' understanding of law. Other malaises of the legal system can be located, albeit often indirectly, in such 'Command' ideas about laws as well as the goals and purposes of the legal system stemming from such ideas.

It is well-known that around one-third of the period (1975-1990) since liberation, we were ruled by 'commanders', i.e., by chiefs of our armed forces. Their notions of laws cannot but be 'command'. Whether 'law-making' of that period still shapes our understanding of law is an issue which is left outside the scope of this article. However, this article recognizes that a more comprehensive account of our legal system in terms

Some of the ideas discussed in this article were first presented a decade ago in Professor Mahfuza Khanam and Barrister Shafique Ahmed Trust Fund Lecture 2010 at the Asiatic Society of Bangladesh, Dhaka, on $24^{\text {th }}$ July, 2010. I briefly revisited some of those ideas in another public lecture in 2018, which was subsequently included in a collection of constitutional law lectures as 'Culture of Constitutional Amendments: (Contentious) Reflections' in Ahmed Javed (eds), Bangladesh er Shongbidhan: Nana Proshongo (Dhaka: Onno Prokash 2020) 143-156. An invitation to contribute to a special issue on the occasion of the centennial celebrations of the University of Dhaka and its Law Department appeared to present an opportunity to revisit and refine those legal ideas that we as a nation continue to struggle with.

1 Kenneth I Winston, 'Book Review of W.I. Morrison's John Austin, Stanford University Press, 1982' (1984) 3 Law and Philosophy 154, 156.

2 Ibid. Winston goes on - “... a lean grey headed painful-looking man, with large earnest timid eyes and clanging metallic voice ... a very worthy sort of limited man and professor of law", quoting from Morrison's biography. John Austin was appointed to the Chair of Jurisprudence at the University of London in 1827 but had a chequered academic career. 
of the command understanding would also need some scrutiny of the influence of lawmaking by the literal-commanders, i.e., chiefs of the armed forces, but that exercise is left for some leisurely future. ${ }^{3}$

I propose to proceed by way of offering a brief outline of the Austinian command theory, and then provide some examples which epitomize this Austinian understanding of law. In choosing these examples, I have focused on constitutional amendments since these amending acts are an important legislative action requiring the support of twothirds of the Parliament. Constitutional amendments also have the most far-reaching impact on the overall legal system and encapsulate extensive policy changes formulated by the ruling parties. Not all of the 17 amendments to the Constitution neatly fit the Austinian understanding of law, but it may suffice if most of them do. These examples lead to my second proposition that these amendments have created a perilous situation for citizens. My understanding of "peril" originates in a rights-based notion of law. If laws do not facilitate rights, citizens are at peril. Finally, the disjunction between law and morality, i.e., Austinian law and natural law, is posed, at the end. It suggests that perhaps overt and simplistic positivist understanding of law in law-making exercises and judicial interpretation by the highest court may do well to look to notions of natural law.

Now, a number of caveats are in order. First, every depiction of Austinian theory of law or his positivism has found more than one defender in jurisprudential discourse. Understandably, theoretical expositions of laws are not an everyday affair and, hence, literature in this area is not as profuse as our very popular pastime of offering recommendations for enactment of new laws and changes to the existing laws. In recent times, Dworkin had been one of the most important critics of Austin ${ }^{4}$ but then again Austin has several defenders to question Dworkin's depiction of Austin. ${ }^{5}$

As is well known, H.L.A. Hart is credited with reviving positivism by blunting some of the sharper edges of Bentham and Austin. ${ }^{6}$ In many ways, English jurisprudence is largely woven around positivism and its ramifications. Unlike many other jurisdictions, newer expositions of legal theory are yet to find a place of prominence in English legal

3 Here one is not oblivious of the pedantic fact that there were "parliaments" during some of the years under the rule of army generals, but no one will seriously dispute the proposition that these parliaments were "para-military-parliaments" as they never acquired the legitimacy of the post-1990 parliaments.

4 Most notably, Ronald Dworkins, Taking Rights Seriously (Cambridge: Harvard University Press 1977). Needless to say, Dworkins tackles not Austin per se, but positivism generally. Austinian are, nevertheless, riled and have rebuked Dworkin. Assessment of Dworkin or his detractors is beyond the scope of this article.

5 Lloyd L. Weinreb, 'Law and Order' (1978) 91(5) Harvard Law Review 909-959.

6 "Within a few years of his death it was clear that his works had established the study of jurisprudence in England. And it is now clear that Austin's influence on the development of in England of the subject has been greater than any other writer", as characterized in H.L.A. Hart, 'Introduction' in John Austin, The Province of Jurisprudence Determined (London: Weidenfeld \& Nicolson 1954) quoted from Wayne Morrison, Jurisprudence: From the Greeks to Post Modernism (New Delhi: The Lawman (India) Private Ltd, 1997) 218, footnote 10.

Page $\mid 74$ 
theory. ${ }^{7}$ In sum, I only touch upon a crude version of Austinian understanding of law without delving into its defense or refutation or considering subsequent refinements. Hence, this article is not about Austinian notions and concepts of law. Secondly, my examples and characterizations of some laws as reflective of the command theory is eclectic. These examples, almost by definition, cannot be beyond disagreement or criticism as one can always read a different meaning into the goal, purpose, or structure of any law. ${ }^{8}$ The most this article strives to achieve is to point towards the possibilities of our lopsided understanding of law, at least in some instances.

This article is divided into three parts. Part I briefly outlines the Austinian Command Theory of Law and sets the central theoretical background for the remainder of the article; Part II examines a series of amendments to the Constitution of Bangladesh as examples that variously epitomize the Austinian understanding of law. The final part of this article concludes with an invitation to move beyond such Austinian approaches in making, interpreting, and understanding law in Bangladesh.

\section{I.}

Austin is sometimes difficult to grasp. This article, as already indicated, is not about Austin's jurisprudence, nor a scrutiny of his definition of law. Plenty has been written about it. Neither is this paper about the actual reflection of Austin in our law, lawmaking and, to a certain extent, our legal system. Instead, this paper engages in certain reflections of a somewhat crude variety of the Austinian notions and conceptions of law in our legal system.

Salmond on Jurisprudence is certain to qualify as the most familiar textbook title to law students for at least last half a century or so. ${ }^{9}$ The sub-title on Austin's theory in Salmond's book is - "Law as the Command of the Sovereign" and goes on to elaborate that Austin had sought to define law:

“... not by reference to its content but according to the formal criteria which differentiate legal rules from other rules such as those of morals, etiquette, and so on. ....... According to Austin, whose version of the theory will be considered here, positive law has three characteristic features. It is a type of command; it is laid down by a political sovereign and it is enforceable by a sanction. ${ }^{10}$

As for the background to Austin's new approach to law (his lectures on Jurisprudence

7 Most notably, the Critical Legal Studies which dominated theorizing about law in the USA during the last quarter century or so has largely remained ignored or on the margin in England. Similarly, the "discourse" (following Foucault) and "Orientalism" (following Edward Said) are yet to be taken up seriously in English jurisprudential studies. Few jurists are sympathetic to these theories in England, but their proponents are, largely, on the margins of academic discourse. Needless to say, theorizing about law is practically unknown to our legal system.

8 After facts are settled, lawyers of the opposite sides put a meaning into the legal provision which suits his/her case/client and hence until the meaning is settled by a precedent, lawyers continue to argue about the meaning, import, purpose, goal and so on of legal provisions.

9 P J Fitzgerald, Salmond on Jurisprudence (Bombay: Tripathi 1985), the first edition was published in 1902.

10 Ibid, 25-26. 
were originally written in 1820-21), Cotterrell has clarified:

" .... The basis of his reputation in legal philosophy, are full of vitriolic comments on the absurdities of common law thought and the irrationality of a legal system, if system it could be called, developed primarily by piecemeal judicial interventions. Bentham viewed judge-made law as like waiting for one's dog to do something wrong and then beating it. Austin, however, was not opposed to judicial law-making. What offended him was the total lack of systematic organization or of a structure of clearly definable rational principles in common law. In his lectures he was determined to map out a rational, scientific approach to legal understanding: a modern view of law that would replace archaic, confused, tradition-bound common law thought and encompass both legislation and judge-made law. ${ }^{11}$

It is understandable that the study of law, against the backdrop of perceived chaotic state of common law, needed to be streamlined and new methods had to be devised to separate law proper from all other rules. In many ways, a somewhat similar scenario can also be depicted for the state of law in late eighteenth century Bengal, after the East India Company assumed the power to dispense criminal justice from 1765 . For the next half a century or more, laws of Bengal were a curious mix of expositions of Muslim law in Company Courts administered by Kazis and a stream of Regulations promulgated by the East India Company. Dispensation of justice through a curious mix of laws expounded by Kazis, mediated by these Regulations, ${ }^{12}$ and further supplanted by the English Judges' own notion of "justice, equity and good conscience" had created a complex legal system which was difficult to understand. ${ }^{13}$

The systematization of laws in our country may be seen to have started with the Penal Code, 1860 to indicate and consolidate the notion that law emanates only from the sovereign and no one else. The mediating influence of Kazis, who until then had acted as interpreters of local and customary laws were done away with by a Regulation of 1862. The nomenclature of "code" of the Penal Code and two other major laws of the British period (Code of Criminal Procedure, 1898 and the Code of Civil Procedure, 1908) had led to an interesting use of the term "codification" of our laws though "code of law", which is a concept of civil law jurisdiction and not of common law jurisdictions.

11 R Cotterrell, The Politics of Jurisprudence: A Critical Introduction to Legal Philosophy (London: LexisNexis UK 2003) Chapter 3.

12 See A Beaufort, A Digest of the Criminal Laws of the Presidency of Fort William and Guide to all Criminal Authorities therein, vol. 2 (Calcutta 1850); R Clark, The Regulations of the Government of Fort William in Bengal, in Force at the End of 1853, vol. 2 (London 1854); R Clarke, Digest or Consolidated Arrangement of the Regulations and Acts of the Bengal Government, from 1793 to 1854 (London 1855); also Shahdeen Malik, 'Perceiving Crimes and Criminals: Erratic Law in the Early $19^{\text {th }}$ Century Bengal' (2002) 6(1\&2) Bangladesh Journal of Law 59; Shahdeen Malik, 'Law of Homicide in Early Nineteenth Century Bengal: Changed Laws and Unchanged Applications' (1998) 2(1) Bangladesh Journal of Law 85.

13 J. Duncan M. Derrett, Essays in Classical and Modern Hindu Law: Current Problems and the Legacy of the Past: Justice, Equity and Good Conscience in India (Brill 1978) 8-27.

Page $\mid 76$ 
The fixation of the authority (by Austin) to enact law with the sovereign and characterization of law as the command of the sovereign certainly served the useful purpose of systemization of our understanding of laws and the legal system. More importantly, this is a simple definition which, perhaps because of its simplicity, was widely accepted.

Natural law, that is the definition of law based on moral concepts and "inherent" notions about right and wrong, are more complex. Any discussion, of law or valid law or proper law which attempts to validate laws from the standpoint of morality or right or wrong inevitably leads to debates and disagreements about 'whose morality, which idea about right or wrong' and so forth, should be reflected in these laws. These debates and uncertainties about morality provided the main thrust for the acceptance of a sanitized version of law as command, which was primarily concerned with whether the command was issued from/by the political sovereign. Austin's definition avoided the pitfall of being bogged down into debates about the morality of the command. The issue has been simply put in the following words:

"Positivists deny that law and morals are connected to one another in any essential or necessary way; defenders of natural law theories assert that there is such a connection." 14

H.L.A. Hart, has described legal positivism as "the simple contention that it in no sense a necessary truth that laws reproduce or satisfy certain demands of morality, though in fact they have often done so." ${ }^{15}$ A.P. d'Entrèves, an eminent spokesman for natural law, has observed that "its most constant feature all through the ages [is] the assertion of the possibility of testing the validity of all laws by referring them to an ultimate measure, to an ideal law which can be known and appraised with an even greater measure of certainty than all existing legislation." ${ }^{, 16} \mathrm{He}$ has also said:

[T] he very assertion of natural law is an assertion that law is a part of ethics, [and] its essential function can appear only as that of mediating between the moral sphere and the sphere of law proper. The notion of natural law partakes at the same time of a legal and of a moral character. Perhaps the best description of natural law is that it provides a name for the point of intersection between law and morals. ${ }^{17}$

More simply, if a person ignorant in law, nevertheless, does something which he thinks is right or refrains from doing something which he thinks is wrong, such actions will most probably stem from his own understanding of right and wrong. Such action or refrain may coincide with legal provisions on that issue. What he has done or refrained

14 Lloyd L. Weinreb, 'Law and Order' (1978) 91(5) Harvard Law Review 909- 959, 909.

15 H.L.A. Hart, The Concept of Law (London: Oxford Clarendon Press 1961) 181-82, as quoted by Weinreb above.

16 A.P. d'Entrèves, Natural Law (Hutchinsons University Library 1951) 93, as quoted by Weinreb above.

17 Ibid, 95, as quoted by Weinreb above. 
from doing was that which law had exactly commanded. It is immaterial for this person that the law which he is unknowingly abiding was the command of the sovereign. These legal provisions (doing or refraining from doing) is not dictated by a sovereign under the threat of sanction or punishment but by the person's own morality. To facilitate adherence or compliance with law, the law must be based on or reflect moral values.

This central position of natural law is submerged under the Austinian understanding of the "sovereign." For Austin, the command to be obeyed as law must satisfy a second condition; that it is issued by a determinate or determinable sovereign.

During the colonial times of Austin, political independence of the sovereign was posed in terms of whether the sovereign was under obligation of any other body/person or not, and not whether the ultimate sovereign was local or unlocal. In other words, it did not matter even if the ultimate sovereign was located in a foreign soil (the so-called metropolis). British law-making in nineteenth century British-India, initially as Regulations and then as Codes and Acts were all "commands" of the sovereign, though the sovereign was located far away from India. For Austin, the issue of sovereignty had been formulated in the following terms by Dewey:

"The question raised, then, by Austin's conception of sovereignty is precisely whether it resides in a specific numerical portion of the body politic. The question raised (by Austin's conception of sovereignty) is of special interest in the country; for if Austin's theory is correct, the theory of popular sovereignty is obviously wrong, not only in the crude form in which it is ordinarily stated, but in any possible development of it." 18

These tensions between popular sovereignty and command, in almost a perverse way, seem to dominate our law-making and law-interpreting exercises and I turn to such exercises in the following part of this article.

\section{II.}

I shall proceed to locate, in this part, the defining influence of Austinian notion of law as a command of the sovereign by suggesting (a) that the legislature seems to take the law literally as a command, which I show to be the case through an analysis of the content of the constitutional amendments; and (b) the fact that the content of many of our constitutional amendments is positive in nature, i.e., often devoid of moral contents. This, in turn, stems from the perception that since the legislature has the required political authority (sovereignty to enact law), it need not concern itself with the moral content of laws. It is difficult to single out the primary driving force for the state of our "positivistic" law other than the fact that it is the product of historically understood and often path-dependent notions of the commands of a sovereign.

Our legislature has been rather prolific in law-making. The ninth (2009-2013) and tenth

18 Susan Minot Woody, 'The Theory of Sovereignty: Dewey versus Austin' (1968) 78(4) Ethics 313318; see also, John Dewey, 'Austin's Theory of Sovereignty' (1894) 9(1) Political Science Quarterly $31-52$.

Page $\mid 78$ 
(2014-2018) Parliaments had enacted 262 and 193 laws, respectively. ${ }^{19}$ During the periods of "Martial laws", martial law regulations and ordinances were promulgated with much more haste and without, virtually, much serious consideration. The sum total of bills enacted into laws by the Parliament since 1973 will run into more than two thousand (though many of these are "amending" laws and not primary or parent laws). Understandably, a scrutiny of such a huge body of laws is both impractical and unnecessary for our present purposes. Instead, to indicate the influence of the "command" understanding of law of our law-makers, I shall confine myself to our constitutional amendments.

\section{A. The Constitution and Natural Law}

Our Constitution, like most other contemporary constitutions, is concerned with constraining power i.e., to ensure democratic governance through laws and not by the whims of persons. Secondly, and more importantly, the Constitution limits the ambit of power of all constitutional functionaries (e.g., the term of office is for a maximum of 5 years). These limits are also enshrined in the fundamental rights part of the constitution. Any exercise of official power, subject to certain conditions laid down by law, cannot encroach upon these fundamental rights. These limits on power are realized by framing certain fundamental rights, such as those in Article 35 in absolute terms. Certain fundamental rights can be limited but only by enacted laws which must be fair, reasonable, and not inconsistent with the constitution. Furthermore, procedural safeguards also limit executive power by delineating the manner in which such power may be exercised.

The moral content or the natural law part of the Constitution, to my mind, is contained in the Preamble and the Fundamental Principles of State Policy (Part II of the Constitution). The Preamble proclaims “.... the high ideals of nationalism, secularism, democracy, and socialism.....shall be the fundamental principles of the Constitution...... [and] the fundamental aim of the State would be to realize a socialist society free from exploitation and a society in which "equality and justice, political, economic and social will be secured for all...." 20

Article 8 of Part II (the moral contents or natural law part of the Constitution) provides that these principles are not enforceable in a court of law. However, these would be fundamental in governance, in interpretation of the Constitution and "shall form the basis of the work of the State." So far, because of the provision that this Part II is not enforceable in a court of law, our courts have consistently taken a strict view that nothing in Part II concerns a court of law. In a number of cases, parties have sought to rely on some of the Fundamental Principles of State Policy in support of their respective position. However, invocation of the Fundamental Principles has not,

19 'Acts of the $9^{\text {th }}$ Parliament' (Bangladesh Parliament) <http://www.parliament.gov.bd/index.php/en /parliamentary-business/business-of-the-house/bill-and-legislation/acts-of-parliament/acts-of-9thparliament> accessed 14 April 2021; 'Acts of the 10 ${ }^{\text {th }}$ Parliament' (Bangladesh Parliament) <http://www.parliament.gov.bd/index.php/en/parliamentary-business/business-of-the-house/bill-andlegislation/acts-of-parliament/acts-of-10th-parliament> accessed 14 April 2021.

20 The Constitution of Bangladesh, preamble. 
generally, found much favour with the Courts. Courts have almost consistently relied on the proposition that these policies are not enforceable as a right. It is not contended that the Fundamental Principles would be enforceable, but only that a more sympathetic - natural law based - approach would have at least offered some legal mooring to these principles. A rights-based understanding of law, which often stems from a natural law perspective, would have shaped the place of these Principles in our legal system differently. Instead, since these Fundamental Principles are not "command per se", these are largely ignored, even after almost five decades of understanding and interpreting the Constitution. ${ }^{21}$

\section{B. Constitutional Amendments and "Command"}

As indicated earlier, instead of a massive scrutiny of laws from different areas, our focus on the Constitution can best indicate the place of "command" in our legal system. The "command" approach to law is most glaringly evident in our constitutional amendments. So far, the Constitution has been amended 17 times, of which the $5^{\text {th }}$ through the $10^{\text {th }}$, i.e., 6 out of the 17 constitutional amendments were introduced under Martial Law and quasi-Martial Law regimes and we exclude those from our scrutiny. Of these 6 amendments, 2 of them, that is $5^{\text {th }}$ and $7^{\text {th }}$ amendments were not single legislative acts in the conventional sense. Various martial law regulations during 19751979 amended several provisions of the constitution. These regulations were made part of the constitution by one sweeping article of the $5^{\text {th }}$ Amendment. Similarly, other martial law regulations during 1982-1986 were all incorporated into the Constitution by the $7^{\text {th }}$ Amendment. The other 4 out of the 6 amendments during military-led governments were technical in nature. For example, some of these increased the number of women reserved seats in the Parliament and limited presidents to two terms only. Hence, these are excluded from our discussion.

At the risk of slight exaggeration, it may be asserted that almost all the other 11

21 A number of reported cases have referred to the Fundamental Principles. Dr. Ahmed Hossain v Bangladesh and others (1992) 44 DLR (AD) 109 (Art 8), Farida Akhter v Bangladesh (2006) 11 BLC (AD) 156 (Art 8, 9); Ejahar Miah alias Ezharul Haque v Bangladesh and others (2000) 6 BLC (HCD) 644 (Art 9); Ruhul Mannan Helali v Bangladesh (2003) 8 BLC (HCD) 349 (Art 10); Sameema Sultana Seema \& 9 others $v$ Bangladesh (2005) 57 DLR (HCD) 201 (Art 10); Sheikh Abdus Sabur v Returning Officer, District Education Officer-in Charge, Gopalgonj and others (1989) 41 DLR (AD) 30 (Art 11); Professor Nurul Islam and others $v$ the People's Republic of Bangladesh and others (2000) 52 DLR (HCD) 413 (Art 11 and 18); Motiar Rahman and 18 others $v$ Bangladesh (2005) 57 DLR (HCD) 327 (Art 11); Hussain Mohammad Ershad v Bangladesh and others (2001) 6 MLR (AD) 33 (Art 13); Hyundai Corporation v Sumikim Bussan Corporation and others (2002) 54 DLR (AD) 88 (Art 14); Rabiya Bhuiyan v Ministry of LGRD (2007) 59 DLR (AD) 176 (Art 15); Mozahidul Islam v Ministry of Education (2016) 68 DLR 234 (Art 15); Bangladesh v M. R. Khan (1976) 28 DLR (HCD) 215 (Art 16); Faizul Islam (Md) v Bangladesh (2017) 22 BLC 246 (Art. 15, 17, 19); Chairman, National Board of revenue (NBR) v Advocate Zulhas Uddin Ahmed (2013) 18 BLC (AD) 52 (Art 18); Government of People's Republic of Bangladesh v Md. Mushfaqur Rahman (2020) 72 DLR (AD) 211 (Art 18A); Iqbal Hossain Mollah v Director Plant Protection Wing (2007) 59 DLR (HCD) 458 (Art 21).The above is by no means an exhaustive list of all the reported cases that touch on some aspects or other of the Fundamental Principles of State Policy. These and other cases on the Fundamental Principles of State Policy almost invariably provide passing mentions of the Articles involved and often with the observation that these principles are not enforceable. However, some of these cases do emphasize the positive obligation of the State to realize these principles.

Page $\mid 80$ 
constitutional amendments have consolidated and strengthened the power of the Executive, at the cost and perils of citizens. ${ }^{22}$ The following is a short account of these amendments, but with a view to indicate how most of these Amendments have 'periled' citizens. It needs to be pointed out that the primacy of the state over citizens have been a key driving force behind these amendments, i.e., state needs to be preserved and protected and its primacy over citizens emanates from a 'command of the sovereign' understanding of law; consequently, placing citizens at peril.

\section{First Amendment ${ }^{23}$}

The First Amendment created an exception for laws providing for punishment of crimes against humanity, genocide, war crimes and other such crimes in so far as any law for these crimes cannot be challenged on the ground of being violative of fundamental rights by adding sub-Article (3) to Article 47; and also, by adding a new Article 47A to ensure that any such law is immune from challenge on constitutional grounds.

Prosecution of persons accused of crimes against humanity, genocide, war crimes and other such heinous crimes had long been recognized as a universal imperative which over-rides procedural safeguards associated with ordinary criminal trial. Arguably, this Amendment can qualify as a reflection of the emerging post-Second World War global morality of total and unconditional abhorrence of crimes against humanity.

\section{Second Amendment ${ }^{24}$}

The Second Amendment diluted the constitutional protection of the right to liberty (provided in Article 33 of the founding Constitution) by amending Article 33. The Constitution did not provide for arrest or detention under any preventive detention law, i.e., curtailment of the right to liberty without allegations of having already committed a crime; but preventive detention is arrest before the commission of a criminal act, on the suspicion that a person may commit a 'prejudicial act', i.e., an act detrimental to the interest of the state, state's economy, its relationship with other countries. To enable the State to restrain a person or preventing him from committing a prejudicial act, subArticle (3), (4), (5) and (6) of Article 33 were added by this Amendment to facilitate the enactment of preventive detention laws. Retaining the earlier "heading" of Article 33 - 'Safeguards as to arrest and detention' - sub-Article (3) now provided that: "Nothing in clause (1) and (2) shall apply to any person - (b) who is arrested and detained under any law providing for preventive detention". Following this Amendment, the Special Powers Act, 1974 was enacted to provide for preventive detention. $^{25}$

22 I have elaborated specifically on the perils of citizens and constitutional amendments from a rightsbased perspective in Shahdeen Malik, 'Culture of Constitutional Amendments: (Contentious) Reflections' in Ahmed Javed (eds), Bangladesh er Shongbidhan: Nana Proshongo (Dhaka: Onno Prokash 2020) 143-156.

The Special Powers Act 1974. (Act No. XIV of 1974) [9 February 1974]. 
It is well-known that under the Special Powers Act, 1974, tens of thousands of people had been detained during the first three decades of its operation, but now (from the early part of this century) the Supreme Court of Bangladesh has made it almost impossible for the Government to detain someone under this Special Powers Act, 1974. In other words, through a series of Judgements from the early 1980s, the Supreme Court tried to limit the power of detention by embarking on the path of declaring most detentions illegal and, hence, ordered the release of detained persons. Gradually these detentions came to be routinely declared illegal. Sometimes the detaining officials of the Government were even rebuked and censured by the Court with the result that preventive detention under the Special Powers Act, 1974 is now hardly applied.

This Amendment, the consequent law and its treatment by the courts reflected an important constitutional tension. On the one hand, this amendment epitomized the command theory as it drastically curtailed the basic and fundamental right of liberty. On the other hand, the courts had taken a firm stand in favour of this fundamental right by virtually abolishing the power of the government to detain a person under the Special Powers Act, 1974. This withering away of the power of the government to preventively detain was not done through a single or even a few judgments. The chipping away of this power was done through hundreds of judgements over roughly a period of a quarter of a century , from early 1980s to the middle of the first decade of this century. ${ }^{26}$ In a remarkable detention case in which leaders (such as Dr. Khondker Mossarraf Hossain, Mirza Abbas and others) of the main opposition political party (the Bangladesh Nationalist Party) were detained in 1997, the High Court Division not only ordered their release by declaring their detention illegal; but also ordered the government to pay compensation of Taka one lac to the detainees. ${ }^{27}$ Nevertheless, the fact remains that this Amendment, under which tens of thousands of citizens were detained over a period of three decades, was a very perilous 'command' for citizens.

The other part of this Second Amendment introduced detailed provisions for the proclamation of emergency. Provisions relating to the proclamation of emergency were contained in Article 63 of the Constitution, which had provided that "in case of actual war or imminent invasion of Bangladesh by land, sea or air the President may take whatever measure he considers necessary for the protection and defense of Bangladesh...." ${ }^{28}$ Furthermore, sub-Article (3) of this Article 63 had provided that "nothing in this Constitution shall invalidate any law enacted by Parliament which is expressed to be for the purpose of securing the public safety and preservation of the State in time of war, invasion or armed rebellion." (italicized)

Clearly, emergency in terms of taking steps by the President and enactment of laws in

26 For an earlier discussion on the Special Powers Act and judicial review concerning this Act, see Shahdeen Malik, "Chapter 3: Bangladesh" in Andrew Harding \& John Hatchard (eds) Preventive Detention and Security Law: A Comparative Survey (Netherlands: Martinus Nijhoff Publishers 1993); see also, Quazi Reza-Ul Hoque, Preventive Detention Legislation and Judicial Intervention in Bangladesh (Dhaka: Bishwa Shahittya Bhavan 1999).

27 Bilkis Akhter Hossain vs Bangladesh (1997) 17 BLD (HCD) 395; the Appellate Division, however, had stayed the part regarding compensation. The petitioners do not seem to have pursued their claim for compensation in the Appellate Division.

28 The Constitution of Bangladesh, Art. 63.

Page $\mid 82$ 
derogation of the Constitution was permitted only "in time of war, invasion or armed rebellion". Instead of these two very restricted sub-Articles, a whole new Part IXA was inserted which provided for the proclamation of emergency in a wide variety of situations ("... in which .... economic life of ... any part ... is threatened") and such emergency may be proclaimed even before the actual occurrence of the dire situation. ${ }^{29}$

A Proclamation of Emergency empowers the Government to enact laws in derogation of six Articles of the Constitution (namely Articles 36, 37, 38, 39, 40 and 42) and suspend the enforcement of these six Articles. However, the Appellate Division of the Supreme Court of Bangladesh has taken the sweeping position that no fundamental rights can be enforced during emergency:

"The President in terms of Article 141C (1) is empowered to suspend the enforcement of any of the fundamental rights conferred by Part III during the period when a Proclamation of Emergency is in operation. It is for the President to decide the enforcement of which of the fundamental rights should be suspended during the operation of the Proclamation of Emergency. This power is not liable to be circumscribed or limited by any other provision in the Constitution including Article 26. Once a Proclamation of Emergency has been made the security of Bangladesh or any part thereof invest in the President all out power to suspend the enforcement of any of the fundamental rights conferred by Part III of the Constitution. This is necessary to keep up and maintaining the welfare of State. As a matter of fact, there is no scope for enquiry into the question whether the fundamental rights the enforcement of which the President has suspended under Article 141C (1) has anything to do with the security of Bangladesh which is threatened whether by war or external aggression or internal disturbance. If the President considered the suspension of the fundamental rights to be necessary during the subsistence of the Proclamation of Emergency, it should be taken to have been made in the interest of security of Bangladesh and no further proof of the security is necessary. We therefore find no force in the argument advanced by Mr. Islam. The learned Judges of the High Court Division have therefore erred in disposing of the rule in the writ petition under reference making the same absolute by enforcing the aforesaid fundamental rights while the proclamation of emergency was operative in the country" ${ }^{130}$

Clearly, the emergency provisions of Article 141A to 141C of Part IXA cannot envisage a situation in which citizens of this country will be without any fundamental right whatsoever. Any scenario in which the Supreme Court is debarred from enforcing any fundamental right is, in my mind, identical to a situation in which the country is without a Constitution or where the Constitution has been abrogated. In other words, an understanding of the Constitution that it merely provides for posts and positions and institutions, but no right of citizens is an idea which can emanate only from a very crude and mechanical understanding of the 'command theory of law'.

29 The Constitution of Bangladesh, Part IXA.

30 Ataur Rahman and others v B.M. Mohibur Rahman and others (2009) 14 MLR (AD) 138, 147. 
Provisions of emergency read through the lens of natural law or mediated by ideas of natural law will lead to the reading of these provisions to mean that only the specified 6 Articles can be suspended (all of which relate to 'political' rights of freedom of movement, assembly, association, speech, profession, and property), and not any of the other freedoms such as life, liberty, non-discrimination, or prohibitions against retrospective law, double jeopardy, torture and so forth. A blanket reading of the emergency provisions of Articles 141B and 141C, as the Appellate Division seems to have done in the above case, would also imply negation of the freedom of religion, which is an absurd proposition. ${ }^{31}$

\section{Third Amendment ${ }^{32}$}

This is the most innocuous amendment in the sense that it embodied a treaty between Bangladesh and India regarding the mutual exchange of some border-enclave. This treaty had to be incorporated into the constitution through the Third Amendment after it was challenged in Kazi Mukhlesur Rahman vs. Bangladesh. ${ }^{33}$ The Supreme Court ruled that the Government could not change the land borders or landmass of the country without incorporating those changes in the Constitution. Hence, the Parliament duly enacted the India-Bangladesh treaty as part of the Constitution in the Third Amendment. This was an instance of positivism insofar as this amendment was enacted to overcome procedural impropriety as pointed out by the Supreme Court. This Amendment, therefore, was a post facto validation of an ostensibly improper executive action and thus, constituted positivist law-making.

\section{Fourth Amendment ${ }^{34}$}

The Fourth Amendment to the Constitution, as is well known, was substantially repealed by the Fifth Amendment. ${ }^{35}$ Though the Fourth Amendment was repealed, it also very clearly stemmed from the notion of the primacy of sovereign command as law, in derogation of almost all notions of democracy, rights and freedom-principles, some of which were fundamental to the founding of the country and enumerated in the Preamble of the Constitution. A couple of provisions of the Fourth Amendment would suffice to illustrate the command notion of law embedded in it. Article 44 of the Constitution had provided that the right to enforce fundamental right is itself a fundamental right. However, the Fourth Amendment replaced Article 44 with the following Article 44:

\footnotetext{
31 One cannot but wonder whether our Appellate Division in 2009 considered governance and constitution to only relate to laws relating to functions of governance in the sense that its only function was 'to rule'. The constitutional document of the colonial era, i.e., the Government of India Act, 1935 is a case in point that encapsulates such notions. It did not contain any chapter or part on any fundamental or human rights. The 1935 Act was primarily about powers and functions of institutions with a view 'to rule'.

32 The Constitution (Third Amendment) Act 1974 (Act No. LXXIV of 1974) [28 November 1974].

33 Kazi Mukhlesur Rahman v Bangladesh (1974) 26 DLR (SC) 44.

34 The Constitution (Fourth Amendment) Act 1975 (Act No. II of 1975) [25 January 1975].

35 The Constitution (Fifth Amendment) Act 1979 (Act No. I of 1979) [6 April 1979].
}

Page | 84 
"Parliament may by law establish a constitutional court, tribunal or commission for the enforcement of rights conferred by this Part;",36

and deleted Article 102(1) which had given the High Court Division the power and authority to enforce fundamental rights. ${ }^{37}$

A host of other provisions of the Fourth Amendment banned most political parties, curtailed freedom of expression and association, made the Supreme Court subservient to the dictates of the President and so forth - in effect, obliterating most of both procedural and natural law contents of the Constitution.

Clearly, the primacy of state over citizens, which is justifiable under a strict command theory of law as the Amendment was duly enacted by the Parliament (the law-making sovereign) and there is no question that it was a law in terms of the command theory. Any criticism and opposition to the provisions of the Fourth Amendment can only stem from natural law concepts of rights, justice, and orderly society. To my mind, the fact that there are not too many defenders of the Fourth Amendment now is a tacit recognition that it was contrary to natural law.

As indicated earlier, we shall not indulge in any scrutiny of the Amendments of the Constitution brought about by the Martial or quasi Martial Law regime and skipping these amendments, we shall proceed to the Eleventh Amendment of the Constitution.

\section{Eleventh Amendment ${ }^{38}$}

The Eleventh Amendment is a curious one and difficult to neatly fit into either positive or natural law compartments. This Amendment was enacted to retrospectively validate continuity in the government as President General H.M. Ershad was ousted from office through a popular movement in December 1990. Consequently, a legal mechanism had to be invented to replace the ousted president with a person who was acceptable to the Main Political Alliances (while general elections were pending). There was general consensus at the time that the incumbent Chief Justice, Shahabuddin Ahmed was acceptable to all political parties. Therefore, the transition of power under a caretaker government was overseen under the leadership of Shahabuddin Ahmed who subsequently returned to his post as Chief Justice. This mechanism for a single election and democratic transition was subsequently validated by the Eleventh Constitutional Amendment.

The preamble to this amendment acknowledged the struggles of the people and "the Main Political Alliances", regardless of their beliefs and ideas, to establish a neutral caretaker government to oversee a credible general election. Thus, the Preamble referred to the popular sovereignty of the people, as opposed to the sovereign power wielded by a select group or persons.

The preamble to the Amendment stated that "upon a positive assurance of the Main

36 The Constitution (Fourth Amendment) Act 1975, s 3.

37 The Constitution (Fourth Amendment) Act 1975, s 17.

38 The Constitution (Eleventh Amendment) Act 1991 (Act No. XXIV of 1991) [10 August 1991]. 
Political Alliances and parties .....he [Shahabuddin Ahmed] would be eligible to return to the post of Chief Justice of Bangladesh ...". ${ }^{39}$ This provision validated the taking of the office of Vice President by Chief Justice Shahabuddin Ahmed and his subsequent return to the office of the Chief Justice of Bangladesh.

From the standpoint of positive law, there is hardly any difference between the Fifth and Seventh Amendments, which are post facto validation of taking over the highest offices. The Eleventh Amendment, on the other hand validated Shahabuddin Ahmed's entering into the office of the Vice President and then going back to the office of the Chief Justice of Bangladesh. ${ }^{40}$ If one were to look into these two different sets of amendments through the prism of positive law only, then all three Amendments were properly and validly enacted by the Parliament in terms of the requirement of enacting constitutional amendments. The difference, however, between the Fifth and Seventh Amendments, on the one hand, and the Eleventh Amendment, on the other hand, is in terms of natural law. The threshold of the moral content and justification of the Eleventh Amendment is completely different from the two earlier Amendments which validated Martial Law regimes. The Eleventh Amendment, can be justified because it stands not only the procedural correctness of law-making and law-amendment but also because it was a priori based on moral acceptance of the people (represented by the Main Political Alliances and other parties of differing ideologies) ${ }^{41}$

\section{Twelfth Amendment ${ }^{42}$}

The Twelfth Amendment restored parliamentary form of government in Bangladesh,

39 Id., Preamble.

40 On a different note, Shahabuddin Ahmed retired as the Chief Justice in 1994. In 1996, when the Awami League won the parliamentary elections, the parliament elected Shahabuddin Ahmed as the president of the Republic. This assumption of office of the President of the Republic by Shahabuddin Ahmed was challenged in Abu Bakkar Siddique v Justice Shahabuddin Ahmed and another (1997) 49 DLR (HCD) 1, on several grounds, including Article 99. Interestingly, the Eleventh Amendment was not cited in this case and the Rule was discharged, i.e., the claim of the petitioner that Mr. Shahabuddin Ahmed assumed office of the President in violation of the constitution was dismissed. After Ruhul Quddus v Justice M.A. Aziz (2008) 60 DLR (HCD) 511, the law on the assumption of offices by the judges of the Supreme Court has changed and the earlier case of Justice Shahabuddin Ahmed would probably be decided differently now. It was ruled in the Ruhul Quddus case that a judge of the Appellate Division could not enter into another office of profit in the service of the Republic-which includes office of the president.

41 The Eleventh Amendment to the constitution was not inserted in the text of the constitution. Instead, it was inserted as clause 21 of the Fourth Schedule to the Constitution. The Fourth Schedule was titled "transitional and temporary provisions". The constitution in 1972 included 17 clauses in this Fourth Schedule. Over the years, 6 more clauses were added to this Schedule including the Eleventh Amendment which was inserted as clause 21 to the Fourth Schedule. However, the Fifteenth amendment to the constitution in 2011 omitted these six clauses 18-23. As a result, Eleventh Amendment is now not included in the text of the constitution. Hence, the constitutional validity of the Caretaker Government headed by Shahabuddin Ahmed has disappeared from the Constitution.

42 The Constitution (Twelfth Amendment) Act 1991 (Act No. XXVIII of 1991) [18 September 1991].

Page $\mid 86$ 
which was previously changed to the Presidential form by the Fourth Amendment in 1975. The Thirteenth Amendment to the Constitution provided for the Caretaker Government. The Fourteenth Amendment increased the retirement age of the judges of the Supreme Court to 67 years and increased the number of reserved seats for women from 30 to 45 .

The Twelfth Amendment can be seen as resulting in the dispersal of executive power of the Republic from President to a Cabinet. However, Article 55 now provides that the executive power of the Republic shall "be exercised by or on the authority of the Prime Minster", making the Prime Minister almost as powerful as the earlier President under the presidential form of government. ${ }^{43}$ Additionally, Article 48 of the Constitution reduces the post of the President to a titular head only and without any meaningful executive power. ${ }^{44}$ The overwhelming executive authority of the Prime Minister, coupled with the restriction put on the Members of Parliament under Article 70 are, again, moored in the exclusivity of sovereign power understood as powers only of the ultimate sovereign authority and not of the people. ${ }^{45}$

\section{Thirteenth Amendment ${ }^{46}$}

The Caretaker Government introduced by the Thirteenth Amendment is positive law par excellence, devoid of any moral content. A failure to hold free and fair election has led, through this amendment, to the denial of all democratic norms and principles as the State clearly ceases to be a People's Republic for at least three months. Such a cessation of the Republican form, as the experience of the last Caretaker Government (2007-2008) has shown, can be extended for a frighteningly long period of time. As indicated earlier, the blanket understanding of the Emergency powers both by the Executive and the Judiciary, and the duration of the unrepresentative Caretaker Government can be unnecessarily prolonged. A positivistic approach to law will fail to see this as problematic because this situation would be technically 'legally' valid. This technical justification for the two-year long caretaker government was also upheld in Masood $R$ Sobhan v. Bangladesh ${ }^{47}$ Thus, the Thirteenth Amendment and its subsequent interpretation by the Court reflect the predominance of positivism illustrating the instrumental uses of the law-an approach which may serve the sovereign well.

The Thirteenth Amendment was challenged in the HCD of the Supreme Court in Saleem Ullah. ${ }^{48}$ The HCD rejected the arguments of the petitioners by a 2-1 majority and upheld the Thirteenth Amendment. On appeal, the Appellate Division by a 4-3

\footnotetext{
The Constitution of Bangladesh, Art. 55.

The Constitution of Bangladesh, Art. 48.

The Constitution of Bangladesh, Art. 70.

The Constitution (Thirteenth Amendment) Act 1996 (Act No. I of 1996) [28 March 1996].

Masood R. Sobhan v The Election Commission \& ors (2008) 28 BLD (HCD) 317.

M. Saleem Ullah v Bangladesh (2005) 57 DLR (HCD) 171.
} 
majority declared the Thirteenth Amendment unconstitutional. ${ }^{49}$ Interestingly, the petitioner's main grounds-which were upheld in the judgment-for challenging this amendment can be characterized as arguments stemming from a natural law understanding of right and wrong. The petitioners had argued that the non-elected neutral Caretaker Government violated the principle of democracy and the basic structure of the Constitution. The other main argument of the petitioner was that the prospect of becoming the Chief Advisor i.e., head of the neutral nonparty Caretaker Government influenced the choice of chief justices by the government to ensure that those candidates who were favorable to the government would be appointed as the head of the Non-party Caretaker Government during the crucial task of holding national elections. This, it was argued, was detrimental to the independence and neutrality of the judiciary. The Appellate Division had invited 8 of the most prominent lawyers as amici curiae including Dr. Kamal Hossain, the chair of the Constitution Drafting Committee of 1972. All of them, save two, supported the Thirteenth Amendment, arguing that the temporary non-elected caretaker government served the greater democratic goal of ensuring free and fair elections. However, their arguments were rejected by the majority of judges.

There was, thus, an interesting juxtaposition of the views of amici curiae on the one hand, and majority judges on the other. The lawyers adopted a natural law understanding on the logic that temporary loss of democratic governance in accordance with law i.e., the Thirteenth Amendment consolidated democracy by ensuring fair elections. The majority judgment, on the other hand, took the purest positive law position that the country cannot deviate from elected democratic governance even for a day as that would be contrary to democratic principles. The majority position was that governance of the country ought to maintain popular representation at all times since Bangladesh is a "People's Republic". ${ }^{50}$

\section{Fifteenth Amendment ${ }^{51}$}

After the pronouncement of the "order" portion of the judgment in May 2011 but prior to the publication of the full judgment which declared the Thirteenth Amendment unconstitutional, the Parliament promptly enacted the Fifteenth Amendment in July 2011. This amendment omitted the Caretaker Government chapter of the Constitution. Elections held since then, that is to say, the general elections of 2014 and 2018 have resulted in landslide victories for the ruling party, the Awami League.

49 Abdul Mannan Khan v Bangladesh (2012) 64 DLR (AD) 169. Saleem Ullah, the petitioner in the High Court Division case mentioned earlier passed away before the appeal was heard in the Appellate Division. Saleem Ullah was substituted by Abdul Mannan Khan as the appellant. Interestingly, the Thirteenth Amendment was earlier challenged on different technical grounds in Syed Muhammad Mashiur Rahman $v$ Bangladesh (1997) 17 BLD 55 and the petition was summarily rejected.

50 For contrasting scholarly opinions on this judgment, see M. Jashim Ali Chowdhury, 'Elections in 'Democratic' Bangladesh' (for an appreciative account) and Ridwanul Hoque, 'The Judicialization of Politics in Bangladesh' (for a critical) in Mark Tushnet and Madhav Khosla, Unstable Constitutionalism - Law and Politics in South Asia (Cambridge University Press 2015).

51 The Constitution (Fifteenth Amendment) Act 2011 (Act No. 14 of 2011) [3 July 2011].

Page $\mid 88$ 


\section{9. $\quad$ Fourteenth Amendment ${ }^{52}$}

The Fourteenth Amendment was enacted in May 2004. It primarily changed the retirement age of judges of the Supreme Court from 65 to 67 years. The amendment also increased the number of reserved seats in the Parliament for women to 45 and some other changes. The enhancement of the retirement age of judges immediately led to protests from various quarters. This enactment was promptly followed by public protests against the Fourteenth amendment to purportedly install a particular person as the head of the next Caretaker Government.

As I have been arguing in this article, the extreme version of the command understanding of law can lead to a legal regime without any moral foundation as starkly posed (more than the caretaker government) by the increase of the retirement age of the Judges to enable one particular person to become the head of the next Caretaker Government. Such positive law, though impeccable in procedural terms (law only as the command of the political sovereign), does not create any moral obligation to obey the law. The fact that we frequently characterize ourselves as a nation which is deficient in qualities for abiding by or adhering to laws, perhaps stems not so much from some traits of our character but from the laws which we do not feel morally obliged to follow-because it does not reflect the aspirations of the people. The Fourteenth Amendment, as mentioned above was widely perceived as a piece of legislation to facilitate the re-election of the then-incumbent government i.e., a piece of self-serving legislation by the government. The Nonparty Caretaker Government was ushered in by the Thirteenth Amendment to ensure free and fair election, but the Fourteenth Amendment diluted the non-partisan character of the caretaker government. The Fourteenth Amendment - a positive law to achieve certain perceived dubious purposes - undermined the moral legitimacy of a nonparty caretaker government by turning such government into a quasi-partisan one.

\section{Sixteenth Amendment ${ }^{53}$}

The instrumental use of law as demonstrated by other amendments discussed earlier continued with the Sixteenth Amendment to the Constitution, enacted by the Parliament in September 2014.

In 1972, the constitution had provided for parliamentary impeachment procedures for removal of judges of the Supreme Court, Election Commissioners and two other constitutional offices of technocratic nature. They were to be removed by votes of at least two-third majority in the Parliament after an investigation found them guilty of gross misconduct. This procedure for removal was first changed by the Fourth Amendment in January 1975 under which the President could unilaterally remove judges among other posts.

The one-party state with quasi dictatorial power for the president created by the Fourth amendment was dismantled through a number of Martial Law proclamations and

52 The Constitution (Fourteenth Amendment) Act 2004 (Act No. 14 of 2004) [17 May 2004].

53 The Constitution (Sixteenth Amendment) Act 2014 (Act No. 13 of 2014) [22 September 2014]. 
regulations during the latter half of 1975, 1976 and 1977. One of these martial law proclamations amended Article 96 of the Constitution to introduce a Supreme Judicial Council (SJC) consisting of the Chief Justice of Bangladesh and the next two seniormost judges of the Appellate Division to investigate allegations of physical or mental incapacity of, or gross misconduct by any judge of the Supreme Court. The SJC was authorised to recommend to the president the removal of the said judge in question if found guilty of the allegations - and its findings would be final.

Although the Supreme Court reviewed various Martial Law proclamations and regulations over time, it did not declare the SJC unconstitutional. The SJC was retained in its original form until the Sixteenth Amendment was enacted. With hindsight, it appears that the Parliament, without any ostensible and acceptable legal or political justification, had suddenly decided to enact the Sixteenth Amendment. One may speculate, however, based on several media reports that public spats between a judge of the Supreme Court and members of Parliament may have led to the enactment of this Amendment. ${ }^{54}$ To reiterate, this Amendment had allowed the Parliament to remove judges.

This Amendment is clearly a unilateral assertion of power of the Parliament over the judiciary. Impeachment procedure for the Judiciary through the Parliament is not uncommon in South Asia. However, this sudden assertion of the power of impeachment clearly manifests the positive understanding of law i.e., 'command of the sovereign' to do as it pleases as well as an instrumentalist understanding of law as a means to achieve certation goals. Concerns about whether or not this assertion of parliamentary power over the judiciary had support among lawyers, judges and several other segments of the society did not figure prominently in the enactment process.

Like several previous constitutional amendments, the Sixteenth Amendment was also rushed through the parliament and made into a law within a very short period of time. The general discontent and opposition to this amendment was reflected in the prompt filing of a judicial review petition by a Supreme Court lawyer, challenging its constitutional validity. ${ }^{55}$ Unlike the Thirteenth Amendment judgment (Abdul Mannan Khan $v$ Bangladesh) in which the bench was divided 4-3, all the 7 judges of the Appellate Division unanimously declared the Sixteenth amendment unconstitutional.

The Court found that the procedure for removal of judges by the Parliament was detrimental to the independence of judiciary. Therefore, the Sixteenth Amendment violated the basic structure of the Constitution. Furthermore, Article 70 of the Constitution prohibits any member of parliament to vote against the party in the Parliament. ${ }^{56}$ Hence, the leading judgment (by the Chief Justice) held that in an impeachment proceeding, no member of parliament will be able to exercise her

54 'Constitution 'violated' by Justice Manik' The Daily Star (Dhaka, 6 June 2012) <https://www.thedailystar.net/news-detail-237159> accessed 14 April 2021.

55 Advocate Asaduzzaman Siddiqui v Bangladesh (2016) 24 BLT (Special Issue) (HCD) 1 and on appeal Government of Bangladesh \& Others v Advocate Asaduzzaman Siddiqui and others (2017) 25 BLT (Special Issue) (AD) 1.

56 The Constitution of Bangladesh, Art. 70.

Page $\mid 90$ 
independent judgment about the judge who is being impeached as she will have to follow the dictates of the head of the political party. As such, whether a judge should be removed or not will depend on the decision of the political party, if not only its leader.

Somewhat similar to the Thirteenth Amendment judgment, the judges in the Sixteenth Amendment case were swayed by a natural law understanding of independence of the judiciary. Any derogation from this concept was sufficient to render the impugned constitutional amendment unconstitutional.

The above narrative, thus, sustains the view that almost all the constitutional amendments clearly reflected a command understanding of law. Those amendments were addressed to the people and the addressees are to obey without question. Another interesting feature of most of these amendments is that almost all of them were rushed through the Parliament within less than a week. In other words, there were hardly any deliberation on these amendments in the Parliament. This process of enactment of constitutional amendments fortifies the notion that the 'sovereign' perceived these as command and did not feel the necessity to consult those that were to obey them.

\section{III.}

Socrates is famously credited with the idea that laws, what may come, must be followed and from his obligation to obey the law, he took poison and died.

This total and unconditional obligation to obey the law is usually traced from, among others, Hobbes ${ }^{57}$, to Kant and then to Austin. In this view, sanction or threatened sanction is the backbone for obedience to law. Natural law has posited that the obligation to obey law stems not only from the positive considerations that it is so dictated by law itself and that disobedience will result in pain (or loss of utility and sufferance pain, in Bentham's understanding); but because "my obedience to law is also based on my concerns and considerations for the well-being or rights of others. I obey law, not only because it is prudent for me to do so (otherwise I shall be punished), but also because I must find some moral reason to obey law". 58

Without delving into these issues of the origin of the obligation to obey law, it is clear to me that the very Austinian understanding of laws and enactment of such "command" have, over the years, eroded our moral obligation to obey the law. The perception that we are not a law-abiding nation, continuously reinforced by the popular media, insistently lead to demands for more stringent laws to ensure that laws are obeyed for the fear of sanction only. Hence, we find it almost impossible to enact laws without

57 Though Hobbes is often taken to be the initiator of positivism in law, many have argued that his views about laws were also tinkered with moral considerations - see David Dyzenhaus, 'Hobbs and the Legitimacy of Laws' (2001) 20(5) Law and Philosophy 461-498.

58 Philip Soper, 'Moral Value of Law' (1985) 84(1) Michigan Law Review 63, 66. 
draconian sanctions. ${ }^{59}$ Our law-making needs to get away from this Austinian rut.

Before concluding, it needs to be reiterated that intricacies, subtleties, debates, evaluation and assessment of 'command' and natural law theories are not the purpose of this article. Furthermore, this article also did not delve into more recent academic writings on these two schools of thought. The history of the debates in the field about these theories, however, are quite interesting and instructive. For example, it is well established that Hans Kelsen was not sufficiently aware of Austin's Magnum Opus ${ }^{60}$ when Kelsen wrote his Pure Theory of Law. ${ }^{61}$

Kelsen's criticism of Austin has been very pointedly surmised by Lars Vinx in the following words:

"Since the Pure Theory of Law limits itself to cognition of positive law and excludes from this cognition the philosophy of justice as well as the sociology of law, its orientation is much the same as that of so-called analytical jurisprudence, which found its classical Anglo-American presentation in the work of John Austin. Each seeks to attain its results exclusively by analysis of positive law. While the Pure Theory of Law arose independently of Austin's famous Lectures on General Jurisprudence, it corresponds in important points with Austin's doctrine. It is submitted that where they differ, the Pure Theory of Law has carried out the method of analytical jurisprudence more consistently than Austin and his followers have succeeded in doing. ${ }^{62}$

In Lars Vinx's depiction of Austinian theory of law that:

"According to Austin, a command is the imperative expression of a will on the part of one person that another person behave in a certain way. What makes a command binding is the fact that the person to whom it is addressed is liable to be subjected to a sanction in the case of non-compliance." ${ }^{\text {"3 }}$

And in criticising Austin, Kelsen's view that (again quoting Lars Vinx):

According to Kelsen, every complete legal norm determines that if a person engages in a certain kind of behaviour (the 'delict'), then a sanction ought to be applied. So understood, legal norms do not, like commands, directly address

59 I had attempted some elaboration on this score in Shahdeen Malik, 'Laws of Bangladesh' in A.M. Chowdhury and Fakrul Alam (eds), Bangladesh: On the Threshold of the Twenty First Century (Dhaka: Asiatic Society of Bangladesh, Dhaka 2002) 433-483.

60 John Austin, The Province of Jurisprudence Determined, first published (1832) followed by several editions and reprints including John Austin, The Province of Jurisprudence Determined, ed by Wilfrid E Rumble (Cambridge: Cambridge University Press 1995). Needless to say, the best-known criticism as well as appreciation of Austin's jurisprudence had been offered by H.L.A Hart, Concept of Law (Oxford: Oxford University Press 1961).

61 Hens Kelsen, Pure Theory of Law (The Lawbook Exchange 2009).

62 Lars Vinx, 'Austin, Kelsen, and the Model of Sovereignty' (2011) 24(2) Canadian Journal of Law and Jurisprudence 473, 474.

63 Ibid, 475.

Page $\mid 92$ 
themselves to those who are to be guided by the law. Rather, legal norms are addressed to those who are to execute the sanction that the law determines ought to follow the delict. In other words, legal norms authorize the application of a sanction on the condition that a delict has been committed." ${ }^{4}$

These intricacies and refinements of the command theory including those by H.L.A Hart briefly touched upon earlier are, however, not important for our present discussion in the paper. As elaborated above, constitutional amendments have been increasingly formulated as commands addressed to the people who have to obey under threat or sanction. These commands are often devoid of any concerns about notions of justice, sociology of law, and other societal construct. This is perhaps best reflected by Article 7A inserted by the Fifteenth amendment to the constitution in 2011:

"7A. (1) If any person, by show of force or use of force or by any other unconstitutional means-

(a) abrogates, repeals, or suspends or attempts or conspires to abrogate, repeal, or suspend this Constitution or any of its article; or

(b) subverts or attempts or conspires to subvert the confidence, belief, or reliance of the citizens to this Constitution or any of its article, his such act shall be sedition and such person shall be guilty of sedition.

(2) If any person-

(a) abets or instigates any act mentioned in clause (1); or

(b) approves, condones, supports, or ratifies such act, his such act shall also be the same offence.

(3) Any person alleged to have committed the offence mentioned in this article shall be sentenced with the highest punishment prescribed for other offences by the existing laws." 65

Article 7A above can be seen to reflect even Kelsenian pure theory of law, in so far as it provides a behaviour which must be observed and details the sanction (albeit in vague, uncertain, and clumsy terms) which will follow if there is a violation. This is important against the backdrop of the fact that until the insertion of this Article 7A, the Constitution could be seen more as a guideline or almost a moral framework as it did not contain any sanction for violation of any of its mandates. ${ }^{66}$ The general remedial provision in the Constitution is contained in Article 102 which authorises the High Court Division to issue any order to enforce rights and remedial measures against different types of unauthorised or illegal actions of, generally, public authorities.

One of the recent refutations of Austin and Kelsen's command understanding of law stems from the recognition that in the wake of the European Union (EU) or the United Nations (UN) Conventions which have become part of national laws, 'the sovereign

64 Ibid, 477.

65

The Constitution of Bangladesh, Art. 7A.

66 The only exception is Article 69 which had provided for a fine of taka one thousand for everyday for a person, who not being a member of parliament, sits and participates in the proceedings of the Parliament. 
has become dispersed among EU or UN member countries. ${ }^{67}$

The above and other nuances of the command theory aside, I view the Bangladeshi Constitution as an embodiment of natural law par excellence. The Preamble and Part II (Fundamental Principles Of State Policy) clearly distinguish the Constitution from a positive/command law in that at least these two do not contain normative prescriptions with sanctions for the delict. The Preamble and Part II of the Constitution reflects aspiration, notions of collective justice and visions of a prosperous and just future. The Preamble declares:

"Further pledging that it shall be a fundamental aim of the State to realise through the democratic process a socialist society, free from exploitation, a society in which the rule of law, fundamental human rights and freedom, equality and justice, political, economic and social, will be secured for all citizens." 68

Similarly, one article from Part II would suffice to reiterate the natural law mooring of the Constitution:

"Article 15. It shall be a fundamental responsibility of the State to attain, through planned economic growth, a constant increase of productive forces and a steady improvement in the material and cultural standard of living of the people, with a view to securing to its citizens -

a) the provision of the basic necessities of life, including food, clothing, shelter, education, and medical care.

b) the right to work, that is the right to guaranteed employment at a reasonable wage having regard to the quantity and quality of work.

c) the right to reasonable rest, recreation, and leisure; and

d) the right to social security, that is to say, to public assistance in cases of undeserved want arising from unemployment, illness or disablement, or suffered by widows or orphans or in old age, or in other such cases." ${ }^{, 69}$

Several similar examples can easily be located in the Constitution. The crux of this article, however, has been that nearly all the amendments to the Constitution were propelled, shaped, or fashioned by almost a singular understanding of law as command of the sovereign with the parliament being, as it were, under the grandiose illusion that it was the 'Austinian Sovereign' which could amend the constitution as it pleased. For a just and equitable society, natural law values and morals now need to be ploughed back into the Constitution. It may be farfetched to suggest further amendments to the Constitution to achieve this. However, the judiciary may have a key role to play by invoking natural law notions into the interpretation of these constitutional amendments.

\footnotetext{
67 Paraphrasing Joseph Raz's critic of Austin and Kelsen in Brian H. Bix, 'John Austin and Constructing Theories of Law' (2011) 24(2) Canadian Journal of Law and Jurisprudence 441, 442.

68 The Constitution of Bangladesh, preamble.

69 The Constitution of Bangladesh, Art. 15.
}

Page | 94 